\title{
Correction to: Forward-looking distribution network charges considering lumpy investments
}

\author{
Niels Govaerts ${ }^{1,2,3} \cdot$ Kenneth Bruninx $x^{1,2} \cdot$ Hélène Le Cadre ${ }^{2,3}$. \\ Leonardo Meeus ${ }^{4,5} \cdot$ Erik Delarue $^{1,2}$ \\ Published online: 24 July 2021 \\ ๑) Springer Science+Business Media, LLC, part of Springer Nature 2021
}

\section{Correction to: Journal of Regulatory Economics https://doi.org/10.1007/s11149-021-09428-1}

The original version of this article unfortunately contained a mistake in one of the coauthor name Hélène Le Cadre. During production process, the name was in-completed. The author name is corrected with this correction.

The original article has been corrected.

Publisher's Note Springer Nature remains neutral with regard to jurisdictional claims in published maps and institutional affiliations.

The original article can be found online at https://doi.org/10.1007/s11149-021-09428-1.

$\bowtie$ Erik Delarue

erik.delarue@kuleuven.be

1 Division of Applied Mechanics and Energy Conversion, Mechanical Engineering, KU Leuven, Celestijnenlaan 300, Box 2421, 3001 Leuven, Belgium

2 EnergyVille, Thor Park, Poort Genk 8310, 3600 Genk, Belgium

3 Flemish Institute of Technological Research (VITO), Boeretang 200, 2400 Mol, Belgium

4 Vlerick Business School, Vlerick Energy Centre, Bolwerklaan 21, 1210 Brussels, Belgium

5 Florence School of Regulation, Robert Schuman Centre for Advanced Studies, European University Institute, Via Boccaccio 121, 50133 Florence, Italy 